\title{
THE KONNOH PEOPLE
}

\author{
INTRODUCTION.
}

KonNor Country is situated on the Liberian border to the N.E. of the Sierra Leone Protectorate, with a small portion across the Liberian border.

The history of the Konnoh people is of great interest. At one time a large and powerful nation residing in $N$. Central West Africa, or perhaps, as tradition states, even further East, they have been driven by the march of time, the laws of necessity, and the fact that might is right, to their present habitation.

Once a strong nation, the Konnohs at the present day have degenerated into an almost insignificant tribe numbering little over 100,000 , which is hardly to be wondered at, when one hears their almost pathetic history of constant war, invasion, and internal strife, up to quite a recent period.

Konnoh Country being situated at the Eastern boundary of the Sierra Leone Protectorate, the people have remained to a great extent untouched by the unavoidable vices of civilisation, and still retain the utmost respect for their tribal authorities.

The character of the Konnohs is a complex one. Crafty and suspicious of every stranger in their country, yet they are easily gulled by any story-so long as it is presented by anyone with the slightest veneer of education. So much is this so, that real cases appear sometimes hardly sufficiently credible to accept for trial in the District Commissioner's Court. Reserved to a degree, and lacking the quick sense of humour so common amongst most West African tribes, yet they can enjoy a joke just as much as others when made by someone with whom they have had previous acquaintance. Timid and nervous when alone out of their own country, they are courageous when en masse, and there are also several cases 
of Konnohs enlisted in the Government forces having been specially rewarded for bravery in action. Gifted with a wonderful sense of imagination, they are quite incapable of either telling the truth, or giving a straight answer in their native disputes. Yet they are loyal and obedient to all proper authority, and they somehow appeal more strongly than others to those who are in charge of their welfare.

In physique, the Konnohs are taller than the Mendi, their features are aquiline, their lips are not of the negro type, and their hair is worn long and plaited.

The country is fertile, and the inhabitants live by growing rice and cotton. Konnoh Country cloths, although of the plainer kind, are well known amongst the neighbouring tribes and form a great part of their merchandise.

The southern part of Konnoh Country is very rich in palm trees. Owing to their inborn hatred of the Mendi, the Konnohs have hitherto not brought down large quantities of kernels to the railway line, which is in Mendi country, but these differences are subsiding, and the last season has shown a marked increase of produce brought down from Konnoh Country.

\section{RELIGION.}

Whilst acknowledging one supreme Deity in Heaven, the Konnohs are essentially Stone and Ancestor worshippers.

In every stone of fantastic shape the Konnohs believe a Spirit, or so-called "Devil," temporarily dwells, and such they worship. Some few special stones exist which are objects of common worship, but generally speaking each person chooses a Devil for himelf. They bring presents of food, \&c., and pray to this Devil, but they are by no means faithful to one, as they likewise concurrently worship the grave of some chosen Ancestor. If things go wrong, the Devil gets the blame; he is at once forsaken for another, and often in addition becomes the object of vituperation and abuse. In times of war or common trouble, each person supplicates his own Devil, and if things do not then prosper the philosophical reason is given, "The Devils could not agree."

As regards the God in Heaven, they recognise Him as 
omnipotent. In their folk-lore $\mathrm{He}$ appears frequently, and is nearly always connected with the creation or taking of life. They state that in $\mathrm{His}$ hands only lies the power of Life and Death (which is somewhat contradicted by their belief in witchcraft and the power of medicine); yet only in the direst necessity and when a person is sick unto death do they make any supplication to this Unknown God.

As regards Death itself, they have a happy belief. Once death cumes all trouble is finished. They believe in a resurrection but in no judgment after death, and also that wealth in this world will count in the next; so that, often, in the case of rirher people a substantial present is buried with the corpse as a "shake-hands" or friendly greeting for presentation on arrival in the Other Land. The question of Eternity has never entered their minds; death to them is a release from all troubles in this world and a clean slate to start with in the next.

\section{Customs, \&c.}

The Konnoh customs are practically identical with those in Mendi and Koranko countries. Their original Porroh and Bundu societies are most decidedly an effort to improve the moral condition of the people, and the consequent moral laws have certainly a good object. Medicine, or rather the fear of it, is the great power in the land to enforce all laws. Every moral law has its own medicine, and at some time or other every man or woman is sworn to obey such laws on these medicines.

Every oath taken is sworn on native medicines; nearly every man has his own medicine to swear others on, and consequently any big native medicine-dispenser is a power in the land. As there exists no native civil force to enforce native laws, although breaches of these laws are dealt with by the Chiefs, the fear of medicine might be described as the great preventive of such breaches.

The Medicine Society is one that has a large membership, which, however, is entirely optional ; and many people do not belong to it. It is essentially a kind of brotherhood with various degrees, and practically all the big men in the country 
are members of it. Every year a few boys are specially chosen to enter the Society and go through a six years' probation, after which they are entitled to set up for themselves as Medicine-dispensers, always subject to the higher degrees of the fraternity.

Konnoh Country is peculiarly exempt from all such disturbing societies as the Leopard, Boa-constrictor, \&c., so common in Mendi land. Yet the one great superstition prevailing is that of witchcraft. Witchcraft is common to a lesser degree in other parts of the Protectorate, yet in Konnoh Country witchcraft is attributed to anything and everything that is beyond their limited understanding. According to their belief there are still men and women who have the power of witchcraft, and who can not only cause the death of newborn children, but maliciously ruin farms and do all sorts of mischief. So firm is the native belief on this subject that when any new-born child dies without apparent reason, it is buried with the solemn warning that unless it arises and destroys the witch that killed it before the fourth day after burial, the witch will devour the corpse on the fourth day. Within one week, at the time of writing this, I have had to deal with three cases in which witchcraft was concerned. The first case was a dispute as to the possession of a witch-gown owned by a deposed Paramount Chief and claimed by his successor. These witch-gowns are supposed to be invisible, except to those whose eyes have been dressed with a special medicine. Such a gown is reported to be made of metal, and not only does it give its owner complete immunity from every kind of witchcraft, but it also greatly enhances his reputation. I asked if anyone had ever seen such a gown, and received a negative reply. Only four are supposed to be in Konnoh Country, and the owners are so eager for protection that they do not make the necessary medicine to let others see them. The deposed Chief in question always appeared before me most shabbily dressed, whilst all the others were in their finest cloths; he had only to remark to the others that he was wearing his witch-gown and at once became an object of admiration and envy. This being a case out of the power of the District Commission, 1 referred it to a Court of native 
Chiefs, who decided that the gown remained the property of the deposed Chief during his lifetime, but reverted to the new Chief on the former's decease. The new Chief is still lamenting the fact that the old one will not make the necessary medicine to permit him to view his future property.

The second case was that of a well-to-do sub-chief, on whom several lawsuits in the Native Court came at once. He summoned a witch doctor from Kissi country to ascertain the person responsible for his misfortunes (or rather his exposures). A regular comedy of complications resulted, and feeling ran very high, which finally resulted in my burning the witch-finder's paraphernalia, making him eat of the ashes; and putting him over the boundary.

The last case was more serious. A child had died in a remote part of the country, whose death was attributed to witchcraft. Immediately a filibustering sub-chief arose, went to the town, described the whole case as a danger to the country, and, as a punishment, took away eight people as domestic slaves. This chief is now reconsidering his action in Kennema gaol.

\section{KONNOH FOLK-LORE.}

The Three Findas; or, Three Kinds of Women.

Now my son, when you go to choose a wife remember the three Findas, marriage is a lottery (literally: "Marriage is an "unknown" "), and any one of the Findas may fall to your share, unless you take care to learn of which kind your Finda may be.

Once upon a time there was a great chief named $\mathrm{Bu}$, who had only one daughter Degbu, and she in her turn had only one daughter called Finda. Now Bu died and all the Chiefs assembled for his burial. At this time Finda was coming to womanhood and was lovely to look upon. Three of the chiefs assembled fell in love with Finda at first sight, and could not wait. Each in his turn went to Degbu and asked for her daughter in marriage. Now Degbu favoured the youngest chief as he was good to look upon, but she was greatly afraid, as times were troublesome in the land, and 
men fought for any fancy that took them. To all the chiefs she replied, "This is no time for seeking my daughter, as my father's burial is now; I cannot give you my daughter at such a time." Now none of these three chiefs would be denied and came again and again. Degbu was in great trouble, as she wished to give Finda to the youngest chief, but greatly feared, as she knew there would be war. Degbu then determined to ask help from God, and calling Finda, she set out for the place where God lived. Now Finda had a dog with her that always followed her, and Degbu took a stick to drive the dog away when they came to the place where God lived. When they came to God's abode the dog would not go, and God asked Degbu her trouble. She said, "Oh! my Father, I have only one daughter and three chiefs want her in marriage, and I can only give her to one, and if I do so, there will be war and many men will die." God spoke to her and said $\mathrm{He}$ would help her if she would acknowledge Him. She answered that if God would help her she would always be His.

Then God took the dog and the stick from her hand, and made them each into a woman, so like Finda that no one could tell them apart. Then Degbu thanked God and returned, and when all her people saw she had three Findas, they were amazed and asked her how this was, and all she would reply was that she now belonged to God.

When the three chiefs came demanding Finda in marriage she gave the stick Finda to the eldest, the dog Finda to the next, and the real Finda to the youngest.

Now my son, in spite of their outward beauty, women are of three kinds since this day. The stick Finda always made trouble from the day of her marriage with the chief, wherever he went; the dog Finda made trouble with anyone who came into her husband's house; and the real Finda gave her husband a happy and joyful life.

You will surely know my son, if you marry and are to have a child of your own, that if your wife abuses you before the baby is born, then you have married a stick Finda, and there is trouble for you not only in your Finda but the child that is to be born. But always remember Degbu 
who in her trouble went to God, and God helped her. Ever afterwards when she was perplexed, she held out her hands and entreated God, and that is why men now in sore trouble hold out their arms and cry "God help me."

\section{The First War on Earth.}

Once long, long ago there was no war in the land, no one ever killed another, and peace was everywhere. A time came when there were many more men than women in the world and then the first trouble began.

Now there was a certain man called Tamba, whose wife was dead, but his son Samba lived with him and grew up a strong man. Now when Tamba was old, he took a young. wife to himself and Samba did wrong, for he courted his father's wife, and his father beat him. Samba then begged his father to get him a wife but his father refused, and at last Samba said, "I will go and beg God to give me a wife."

After many days Samba came to the place where God lived, and begged God to give him a wife. God told him to go and cut wood for $\mathrm{Him}$ and to light His fire and in the evening God slept at the fireside. This happened many days and each day Samba begged God for a wife. One night God told Samba to go into the house and lie down and God covered him with a cloth and charged him not to move or speak until God called him in the morning. Whilst Samba slept, God went out and cut a banana tree, the height of his chin, and came and put this beside Samba as he slept and covered it with a cloth also.

The next morning early God came to the door and knocked and called "Lango, Lango ! get up and open the door." And from where the banana tree had been a woman arose, so beautiful that no man had ever seen her like, and opened the door. Samba wanted to speak to her but feared to do so until God spoke to him. Then God came and told Samba to go and get wood, but Samba pleaded with God for the woman "Lango," and finally God said He would give her to him when he had got more wood.

Samba then brought Lango home to his father's house, and 
when his father Tamba saw Lango he sought to drive Samba away and keep the woman Lango. Then there arose trouble, and for the first time in the world Samba threatened to kill his father Tamba if he interfered with his wife. Tamba then drove his son away and Lango lived with Tamba.

Now Samba could not forget Lango and he loved her still, and he went to a chief called Momodu and persuaded him to take up his cause and send messengers to Tamba asking for his son's wife. When the messengers came to Tamba, he would not give up the woman and killed them, so was the first murder in this world. Momodu was then very angry and began war on Tamba on account of the death of his messengers. Momodu was victorious and Tamba was killed, but when Momodu saw Lango, he loved her at once and took her for wife and drove Samba away with threats.

Samba then went to a chief Fabamba and persuaded him to take up his case. Momodu was defeated, and when Fabamba saw Lango he loved her, and he knew that there would be no peace whilst Samba lived, as Samba loved Lango, so he enticed Samba away and murdered him. Yet there was no peace for Fabamba, for other chiefs saw Lango and loved her, and Fabamba was himself killed, and as long as Lango lived there was continual war.

And so it was that the first war and murder came into this world for the sake of a woman, and it has been so ever since.

\section{Tambafassa.}

Now there was a great war between the Konnohs and Korankos, and the Konnoh people were sore pressed and ran everywhere, and there was no chief left and all the people sought for someone to come and save them, whom they could make chief. Now at this time there lived a poor man, named Tambafassa, on a farm away by himself, and this man was so good and kind that all the birds, bees, filies, and snakes obeyed him; even the ants used to climb over his head, go in at one ear, come out at the other, and not hurt him.

Now Tambafassa heard of the trouble, and called to him the king of birds, the king of bees, the king of gadflies, and the king of snakes, and put them all in a bag and went to 
the meeting of the people and told them that he would save the country alone. Then several people laughed at him, but Tambafassa opened the bag a little and let out the king of the bees, and the king of the gadflies, who stung the scoffers, so all men were silent.

Then Tambafassa went out and loosed the kings of the bees, birds, gadflies, and snakes, and sent them to call all their people, and went to Segwia where the Korankos were. When the Korankos came out they were attacked by the bees and gadflies, and fled into the grass, where the snakes bit them and they fled.

After a time the Korankos rebelled and again attacked Tambafassa who had been made chief of the whole country. Tambafassa lived at Moribundandu at this time, and merely told the bees to settle it; and the Korankos fled. After this everyone feared Tambafassa, who was really a good man, but as time went on Fakoie of Boyia assembled his people to drive Tambafassa out. At this time came certain Mori men [magicians] to Tambafassa and presented him with a white Kola nut, and the report of this went everywhere. Now when Fakoie was talking with his people, Tambafassa called the king of the birds, and gave him the white Kola nut, and as Fakoie was sitting under a tree talking the king of the birds dropped the white Kola nut at his feet. Everyone was so frightened that they all ran away.

When Jafurrie of Jafuyia killed too people in one day to show how big a man he was, the people sent to Tambafassa's son, Kibundafoi, as Tambafassa was sick. Kibundafoi made war on Jafurrie but was beaten. When Tambafassa heard of this he sent out the bees and gadflies again and Jafurrie fled. Tambafassa was buried at Quoidu in a ripe old age.

How Jealousy Spoilt the Rice.

Now at the time Yi Yabba was chief, rice was very different from what it is now. One single seed then, when cooked, would fill a small pot sufficient for one man.

Yi Yabba's wife was old and had no children, so he sent for a new wife from one of the other chiefdoms, and when she came she was accompanied by six of her people. Yi Yabba 
then told his first wife to get six seeds of rice and cook them for these people, but she was vexed and angry and instead of taking six seeds of rice, she took a handful and threw it in a small pot that was on the fire. Now God was very angry at this and came down to earth and came to Yi Yabba and told him that his wife had spoilt the rice that $\mathrm{He}$, God, had given them, and that $\mathrm{He}$ was going to take her away. $\mathrm{Yi}$ Yabba begged God very hard for this woman and said he would be shamed before all men if God did this. God was then very angry and said that as the woman had spoilt the rice, and as Yi Yabba had begged for her, that henceforth one seed of rice should not be sufficient for one man, but that it would take a handful to fill a small pot, and it has been so ever since. Then God called the woman and told her, and as $\mathrm{He}$ was going away he touched her on the head with His finger and the woman's head began to ache and she died a few days after. That is why we, Konnohs, always fear we are going to die if our heads hurt us, and that is how the rice was spoilt for ever owing to jealousy.

Since this time all chiefs have had many wives, so if the head wife does wrong another can be put in her place at once, and there is no need to beg for her.

\section{Division.}

Now if a Konnoh man goes out into his farm and gets Cassada and brings it back, and has fufu made, he calls someone else to help him eat it, and they eat it together, but do not divide it, but you will never see women do this, and this is the reason :

Long, long years ago, when the first farms were made, two women had a farm between them and when the things began to grow, they went out and got some yams and came back and made fufu. When they sat down to eat it, one said to the other, "Now we will divide it equally, so one shall not eat more than the other." The other then replied, "If we divide this then we will divide the farm also," and much trouble arose.

Ever since then no two women have been able to share anything without dividing it up. No two women work 
equally on a farm, one is always above the other, and no two wives share and share alike unless the husband divides.

\section{Jacob and Esau.}

Now after God made the world and the people in it, there were no chiefs and God said: "I will go down into the world among the men and search until I find a man who is good to everyone and I will make him chief over the others."

God then came down to earth like a poor man sick with smallpox, and wherever He went the people drove him away.

One day He came to a town where the young men were playing. $\mathrm{He}$ asked them all to help $\mathrm{Him}$ as $\mathrm{He}$ was a stranger, but they all laughed at Him. There was one man, however, called Jumba, who took pity on Him, took Him into his own house, and fed Him, and let Him sleep there with himself.

In the morning God asked him to go a small way with Him on the road as He wanted to speak to him. When they got outside the town to where two roads met, God told Jumba who $\mathrm{He}$ was, and that $\mathrm{He}$ had decided to make Jumba chief over all the people, and bade him come to the cross roads at dawn next morning, where he would find a heap of leaves. He was to lie down and cover himself with the leaves, and God would send down to him presents, so that all men would know he was to be Chief.

Now Jumba had a wife Guma, who heard the stranger tell Jumba that He wanted to speak to him, and, being curious, followed secretly along the road, and heard what God said. Now Guma had a lover called Bay Marringa, so she waited until Jumba had gone back, and then went and told her lover all she had heard, and bade him take Jumba's place next morning under the leaves, and she would detain Jumba.

At dawn next morning Jumba got up, but Guma put her arms round him and begged him to stay a short time. In the meantime Bay Marringa had gone to the cross roads and covered himself with the leaves. When it grew light a great noise like beating of drums was heard in the air, and a great big box came down to where Bay Marringa was hidden in the leaves. Jumba heard the noise, and ran out 
and came to the cross roads and found Bay Marringa there with all the precious things God had sent down to show he was chief. Then Jumba called loudly for God, and God came and Jumba complained bitterly that Bay Marringa had stolen the things that God had promised him.

Then God said He could not help it now, that the woman had tempted Jumba and that he had listened to her and not done what God had told him; that always after that he must follow Bay Marringa and sing and play behind him, and that Bay Marringa must always give Jumba food and presents when he did this. Bay Marringa then became chief, but was called Massa.

That is why to-day we call our chiefs Massa, and men follow chiefs and sing behind them, and the chiefs give them food and presents for so doing.

\section{HISTORY OF KONNOH." \\ PART I. \\ Romantic Period.}

Many, many years ago, before our grandfathers', grandfathers', grandfathers' time, so long ago that no man can count, the Konnoh people lived happily at a place now in French territory, where the Lelli people live to this day, near a hill which is still called Konnoh Su. Our fathers were driven out from this country in a tribal war, but the people there still talk the real Konnoh language and keep up the customs we have heard of as once belonging to our people. No man there is circumcised until he has a son of his own.

Our fathers then came and settled on the Melli River at Yawando, Yamba, Kongofie, and Sengi Sengi. No one lived in this country at the time, it was all grass, no bush at all. Elephants, lions, and wolves roamed everywhere, leopards also and all kinds of game. Our people gradually spread from the Melli river to Kayima and the Sewa river and down south to near Pendembu, where the line is now. They were a peaceful people, not wanting war, but mighty

1 This appears to be given, as nearly as possible, in the words of the anthor's native informents. $-E_{D}$. 
hunters who fought with all the wild beasts. They had brought with them cows, sheep and goats, but no corn to plant their farms, and collected roots in the fields. The rivers were then only small streams, and there was a scarcity of water. As our fathers had nothing to plant the farms with, they used to follow the tracks of the elephants, where after a time certain grasses used to grow in the elephants' dung, which they planted in the farms, and it was so that rice first came into this country. This is all so long ago that no man can count, but, we the old men, heard it spoken of by the fires in the evening when hugging our mothers' breasts.

The Ancestor from whom we are all descended, Fa Konnoh, was buried at a place called Sungudu, close to Konnoh Su. A tree which we call Donnai grew suddenly out of his grave. All the birds came and picked the berries and scattered them over the country, and wherever a seed was sown a tree grew up. The name of a bird in the Konnoh language is "Konnoh"; that is how we got the name Konnoh as we were like the birds spreading the seed of our Ancestor over the country and raising up families.

Our oldest Ancestor whom we know about was Yara Kafi, who our fathers told us was over 100 generations before our time. When he was Chief there were different laws; no man was allowed more than one wife, and if a man died and he had a married daughter with a son older than his own son, that daughter's son became head of the family.

After this time there lived a Chief in Mendi country called Battoe Wirama, who used to boast, "Let the Konnoh women each bear a child before any of my wives get children, so I can then go and collect the Konnoh children to be slaves to my children." A big war then followed between the Mendis and ourselves. We were strong men then, and our two big war chiefs were Dahibah and Tembaie, who defeated the Mendis, and it was in this war we got Bunakoro from the Mendis, and also most of the Gourama chiefdom, which the Konnohs still hold. Goura is a Mendi word for thick bush. Four Koranko men, Fuli Lamfia, Dampariwa, Wolo Wolo, and Fungutinia, came down from the Tinki Moun- 
tains to help us in this war. After the war was over they were dissatisfied at the division of the spoil and returned home, and in revenge they cut off the heads of every Konnoh man or woman they met on the road, and took the heads back with them to Koranko country. Yara Kafi was an old man then, but he swore revenge and called back Dahibah and Tembaie from fighting with the Mendis and made war on the Korankos. The Korankos were then driven some to Sankara country and some to Fula country. That is how we got most of Sanda chiefdom.

Next we know of Sandia Kurie, grandson of Yara Kafi; he was a bad man, proud and richer than everyone else. He tired of ordinary presents and ordered that when he came to a town two young children should be brought to him. His wife Pimba then killed them before everyone and beat up their bones which she smeared on Sandia Kurie's forehead. Our people then rose in rebellion under Bangaoo of Sengi Sengi. Sandia Kurie and his wife Pimba were beheaded on the banks of the Melli river, their bodies and heads refused burial and thrown into the water. From this time any bad chief was always called Sandia Kurie.

Bangaoo then became chief of all the Konnohs and made the law that is called Bangaoo to this day : that when a chief enters a town he can ask for a cow, sheep, or goat, but not for a person. He made peace everywhere and began the settlement of the country, sending families to settle in various places, which resulted in our present chiefdoms, as the names now show, as, for instance, "Nimmi Korroh," which means Nimmi at the bottom of a hill. A man called Nimmi was sent out and came to the hills above Jahama. Here he found quantities of honey which he tasted and found sweet, he then built Jahama at the bcttom of the hill but called it Nimmi Korroh.

Soa (Sowa) in Mendi and Konnoh means three. A certain woman had three sons but her husband was dead; she went out and made the Soa chiefdom, which has since been known as the "three."

Bensay means a weakling. A certain woman had a weak, sick child and was driven out; then she came to Yaradu and 
the boy grew up, always weak, but he got a family and all the people called his country the weakling.

Kamarra, the land of baboons. And all the other chiefdoms also have names like this. Bangaoo's own country was called Lay, the meaning of which is "too much." All the people were so grateful to him that everyone brought him scmething, so he always had too much.

When Bangaoo died every man amongst the Konnohs came to his burying, they cut sticks and beat them together in time and this was the first Konnoh band and dance ever made. We teach our children to remember Bangaoo and his laws, many of which are in force now.

Quoimandu his son succeeded Bangaoo, but nothing happened when he was chief, and when he died he was succeeded by his nephew Borrowurri.

Now Borrowurri became very rich and came to Massundu where he lived. At this time the Koniki Timini people had no rice at all, and began to make raids when our rice was ripe and stole it. Borrowurri then made war on the Koniki Timinis, and a big fight took place at Kondukoro. Our people were defeated and fled, closely pursued by the enemy, along the road to Bagwema, where there is a great hole in the rocks and the water comes up in the wet season from the Sewa river. Now this hole is so broad that no man can jump it, and our people flying along the road nearly all fell into it, and Borrowurri also. Some few were taken prisoners; they escaped years later, and came and told the Konnoh people what had happened. That is why even to this day we cook rice and fowls and take it to this hole and give food to our ancestors, and sometimes we hear them in the night time beating their drums and calling the people to war.

Now with Borrowurri, all his sons and big men fell into the hole and there was no one left to be Chief. Borrowurri was the last of our big chiefs; after that all Konnoh Country became separate chiefdoms, as they are now, according to the families that had gone out under Bangaoo.

R. H. K. Willans,

(To be continued.) 